\title{
An Internal Reaction Control for Routine Detection of Clavibacter michiganensis subsp. sepedonicus Using a Real-Time TaqMan PCR-Based Assay
}

\author{
Donna S. Smith, Solke H. De Boer, and Jane Gourley, Charlottetown Laboratory, Canadian Food Inspection \\ Agency, Charlottetown, PE, C1A 5T1, Canada
}

\begin{abstract}
Smith, D. S., De Boer, S. H., and Gourley, J. 2008. An internal reaction control for routine detection of Clavibacter michiganensis subsp. sepedonicus using a real-time TaqMan PCR-based assay. Plant Dis. 92:684-693.

An internal reaction control was integrated into a TaqMan polymerase chain reaction (PCR) assay for the detection of Clavibacter michiganensis subsp. sepedonicus, the causal organism of bacterial ring rot of potato. The reaction control, cloned into plasmid $\mathrm{pCmsC4}$, consisted of a sequence unrelated to $C$. michiganensis subsp. sepedonicus flanked by the primer sequences used in the TaqMan PCR, thus eliminating the need for multiplexing. Inclusion of the reaction control plasmid in the TaqMan assay had no effect on either the limit of detection or the specificity of the method. Addition of SYBR Green permitted melt analysis of PCR products. The 242bp reaction control amplicon, with a melt temperature of approximately $94.5^{\circ} \mathrm{C}$, could easily be distinguished from the 152-bp primary diagnostic target amplicon, which had a melt temperature of about $85.5^{\circ} \mathrm{C}$. Electrophoretic analysis showed that appearance of either melt peak correlated well with the presence of the appropriate amplicon. Two different substances, guanidine- $\mathrm{HCl}$ and humic acid, inhibited the amplification of the reaction control at concentrations lower than those that inhibited the primary diagnostic target, demonstrating the reaction control's effectiveness in detecting inhibition or reaction failure. Using the reaction control plasmid, a quantitative threshold for inhibitor detection was established. This permitted the validation of negative results, and thus facilitated the use of TaqMan real-time PCR in the routine testing of diagnostic samples for $C$. michiganensis subsp. sepedonicus.
\end{abstract}

Clavibacter michiganensis subsp. sepedonicus causes bacterial ring rot of potato (Solanum tuberosum L.), a disease that warrants serious concern because of its potential to cause significant economic losses. C. michiganensis subsp. sepedonicus is readily spread through seed potato tubers, particularly by latent infections in which a low incidence of inoculum persists asymptomatically in potato for several generations $(11,18)$. Because sound cultural practices including compliance with strict phytosanitary measures is the only means of controlling the spread of this pathogen, seed certification programs have been implemented in most jurisdictions where seed potatoes are produced.

To support regulatory enforcement, valid and robust laboratory methods are required for the detection of subsymptomatic levels of $C$. michiganensis subsp.

Corresponding author: D. S. Smith

E-mail: smithds@inspection.gc.ca

* The $\boldsymbol{e}$-Xtra logo stands for "electronic extra" and indicates that Figure 8 appears in color in the online edition.

Accepted for publication 8 January 2008.

doi:10.1094/PDIS-92-5-0684

This article is in the public domain and not copyrightable. It may be freely reprinted with customary crediting of the source. The American Phytopathological Society, 2008. sepedonicus. Enzyme-linked immunosorbent assays (ELISA) utilizing a monoclonal antibody (9) are widely used, as they are well suited to large-scale, highthroughput screening, and the required antibodies and reagents are commercially available. Immunofluorescence microscopy (IMF) is also used, sometimes as a confirmatory test for ELISA-positive samples, because it enables the direct visualization of $C$. michiganensis subsp. sepedonicus cells (8). IMF is more laborintensive than ELISA, and interpretation can be subjective.

Nucleic acid-based tests offer an alternative to serological-based detection of plant pathogens, and the comparative advantages and disadvantages of each have been recently reviewed (29). A number of polymerase chain reaction (PCR)-based methods for detection of $C$. michiganensis subsp. sepedonicus have been published $(10,14,15,17,19,25)$. Such DNA amplification-based methods offer much lower limits of detection, but despite the level of specificity and sensitivity that can be achieved with PCR, there are two major factors that have adversely affected its value as a diagnostic tool in a regulatory context. The first is the occurrence of false negative results due to reagent or thermocycler failure or to the presence of coextracting substances in the sample that inhibit the polymerase reaction (28). Potato starch, acidic polysaccharides, and phenolic compounds may be present in tuber or stem extracts, and are known to inhibit polymerase reactions (2). Fungal polyphosphates and humic acid from soil, both potent inhibitors of PCR (2), may also be associated with potato tissue and be co-extracted with DNA.

An internal reaction control can be incorporated into a PCR test to validate negative test results (21). Of several conventional PCR methods for the specific detection of $C$. michiganensis subsp. sepedonicus, the first to include an internal reaction control was a competitive PCR in which an unrelated sequence was added to the reaction mix to be co-amplified with target DNA by the target-specific primers (12). In a later method, an endogenous gene, 18S rRNA, served as an internal reaction control, and was co-amplified using a separate set of primers in a multiplex reaction (20). This approach was also applied for the detection of Ralstonia solanacearum, in which a plastid gene, cytochrome oxidase, was used as an internal reaction control (30).

The second factor limiting the utility of PCR for regulatory work is the significant potential for amplicon carry-over into samples or reagents, which can cause the generation of false positive results (28). Conventional PCR methods require postamplification manipulation, including electrophoresis and hybridization analyses, but such manipulation can result in the dispersal of amplicons throughout the laboratory, contributing to the risk of false positives. The implementation of real-time fluorescence PCR methods, in which the amplicons are detected using doublestranded DNA binding dyes or fluorescentlabeled, sequence-specific probes, eliminates the need to open the reaction tube.

Real-time PCR, with TaqMan probes (16) that utilize the $5^{\prime}$ exonuclease activity of $\mathrm{Taq}$ polymerase to separate quencher and fluorophore moieties on labeled probes, permits measurement of amplified product as the reaction proceeds. By adding a DNA-binding dye such as SYBR Green, postreaction melt analysis of amplicons can also be conducted to confirm amplicon identity directly in the reaction tube (22). At least three real-time amplification methods for the detection of $C$. michiganensis subsp. sepedonicus have been published. A nucleic acid sequence based amplification (NASBA) method, designed for epidemiological studies, en- 
abled the detection of viable $C$. michiganensis subsp. sepedonicus cells (27). A second method targeting the intergenic ribosomal DNA region and utilizing conserved primers and variable TaqMan probes was developed for differentiating subspecies of $C$. michiganensis (1). A third method was formulated as a real-time BIO-PCR assay in which target bacteria are multiplied in a semi-selective medium prior to DNA extraction (24).

The objective of this study was to incorporate an internal reaction control in a real-time TaqMan PCR method based on published primer and probe sequences (24), and to specify a threshold for validating negative test results. A postreaction melt analysis step was incorporated as part of routine testing to confirm amplicon identities within a closed-tube system. The results of this assay were evaluated in comparison to results obtained by serological detection methods conducted within a quality assurance testing program.

\section{MATERIALS AND METHODS}

Bacterial strains and culture conditions. C. michiganensis subsp. sepedonicus strain R14 was used as a positive control and in the spike-recovery experiments. The bacterium was maintained in Nutrient Broth (BD Difco, Sparks, MD) with 50\% glycerol at $-70^{\circ} \mathrm{C}$, and cultured or dilutionplated for enumeration on yeast extractglucose-mineral salts medium (YGM) (5). Plates were incubated at room temperature (ca. $21^{\circ} \mathrm{C}$ ) for 2 to 4 days before use. For DNA preparations where the cells were not enumerated, single colonies were resuspended in sterile water to form a visibly turbid suspension.

Escherichia coli strain DH5 $\alpha$-T1 was purchased from Invitrogen (Carlsbad, CA). Transformant clones derived from this strain were grown in Luria-Bertani (LB) broth (BD Difco) or LB agar supplemented with $50 \mu \mathrm{g} / \mathrm{ml}$ ampicillin (Roche Applied Sciences, Laval, Canada) at $37^{\circ} \mathrm{C}$ for 16 to $24 \mathrm{~h}$.

Custom oligonucleotides. With the exception of the TaqMan probe 50-53T, which was supplied by Integrated DNA
Technologies (Coralville, IA), all oligonucleotides were prepared-to-order by Eurogentec (San Diego, CA). Sequences of all the oligonucleotides along with their source references are listed in Table 1. All original oligonucleotide sequences developed for use in this study were designed using Clone Manager Suite v. 6.00 (Science and Educational Software, Cary, NC).

Potato sample material and preparation of homogenates. Potato tuber samples from discrete production lots were submitted to the laboratory from farm units in various regions across Canada. Cores of vascular tissue $(0.4$ to $1.0 \mathrm{~g})$ were taken from the stolon end of each tuber, washed, weighed, and homogenized in distilled water at a rate of $1 \mathrm{ml} / \mathrm{g}$ tissue using a blender (Waring, Torrington, CT). Typically, samples were composite, each comprised of 200 cores homogenized together. The homogenates were filtered through a double layer of cheesecloth and stored frozen in 50-ml, screw-capped polypropylene tubes until further use.

Total DNA extraction. Bacterial cells in pure culture or in potato homogenates were lysed by mixing $500 \mu$ l homogenate or culture suspension with $200 \mu \mathrm{l}$ of a stock extraction buffer (175 mM Tris- $\mathrm{HCl}$, $\mathrm{pH} 8.0,8.75 \mathrm{mM}$ ethylenediamine tetracetic acid, $3.5 \%$ sodium dodecyl sulfate, and $35 \mu \mathrm{g} / \mathrm{ml}$ proteinase $\mathrm{K}$ ) and incubating $3 \mathrm{~h}$ to overnight at $55^{\circ} \mathrm{C}$. DNA was extracted using the components from the Magnesil KF DNA extraction kit (Promega, Madison, WI). Initially, $500 \mu \mathrm{l}$ of digest was mixed with an equal volume of lysis buffer and $100 \mu \mathrm{l}$ of magnetic beads. The remaining kit components were used to wash and elute the DNA with a Kingfisher magnetic particle processor (Thermo Scientific, Waltham, MA) according to the kit instructions. The extracts were transferred into sterile, nuclease-free microfuge tubes and stored at $-20^{\circ} \mathrm{C}$ or colder until analyzed.

A few samples required postextraction cleanup to remove residual inhibitors. These extracts were diluted into $600 \mu \mathrm{l}$ of Ultraclean Plant DNA buffer P3 (Mo-Bio, Carlsbad, CA) and processed in spin col- umns (Mo-Bio) according to the manufacture's instructions to obtain a purified DNA fraction.

Construction of the reaction control plasmid pCmsC4. An overview of the strategy used to construct $\mathrm{pCmsC4}$ is shown in Figure 1. The reaction control sequence was prepared from three fragments. The left fragment (left arm) and right fragment (right arm) contained the $C$. michiganensis subsp. sepedonicus-specific primer sequences $50-2 \mathrm{~F}$ and $133 \mathrm{R}$, and were generated in PCR from 100-mer synthetic single-stranded oligos using primers ivr-f1 and ivr-r1. The middle fragment (495 bp) was generated in PCR from the corn (Zea mays L.) invertase gene, also using primers ivr-f1 and ivr-r1. The extraction method used to prepare the genomic DNA has been previously described (26).

The 100-bp left and right arm fragments were digested with 0.4 units/ $\mu \mathrm{l}$ of $M l u \mathrm{I}$ and HaeII, respectively (New England Biolabs, Ipswich, MA). The resulting 73-bp fragments were both gel-purified using a Qiaquick gel extraction kit (Qiagen, Mississauga, Canada). The 495-bp invertase fragment was double digested with $M l u \mathrm{I}$ and HaeII, and the resulting 185-bp fragment was ligated to the two 73-bp fragments using T4 ligase (Roche Applied Science).

The ligation products were analyzed on a $2 \%$ agarose gel, and a $400-$ to $450-b p$ product was identified and purified. The desired ca. 240-bp fragment (Fig. 1) was amplified from $1 \mu \mathrm{l}$ of this preparation in PCR using primers $50-2 \mathrm{~F}$ and $133 \mathrm{R}$, and cloned into pCRII-TOPO (Invitrogen) according to the supplier's instructions. Competent cells of E. coli strain DH5 $\alpha$-T1 (Invitrogen) were transformed with $4 \mu \mathrm{l}$ of the cloning reaction, and transformed colonies were selected and cultured for further analysis and characterization.

Plasmid purification and characterization. Plasmids were prepared from overnight cultures of single colonies grown from transformed cells using Wizard miniprep reagents and Wizard Resin (Promega), and quantified using Picogreen (Invitrogen) fluorescence. Preparations were

Table 1. Sequences of oligonucleotides ( $5^{\prime}$ to $\left.3^{\prime}\right)$ used in this study

\begin{tabular}{|c|c|c|c|}
\hline Oligo & Sequence & Function & Reference \\
\hline ivr-f1 & ccggatcgtcatgctctaca & $\begin{array}{l}\text { Forward PCR primer for corn gene ivrl, insert left arm, and } \\
\text { reverse primer for insert right arm (Fig. 1) }\end{array}$ & This study \\
\hline ivr-r1 & gtgccgatcgcgtagtagtc & $\begin{array}{l}\text { Reverse PCR primer for corn gene ivrl, insert left arm, and } \\
\text { forward primer for insert right arm (Fig. 1) }\end{array}$ & This study \\
\hline Insert left arm & $\begin{array}{l}\text { ccggatcgtcatgctctacacggaagcttaggcggagtcgtccggagcgcgata } \\
\text { gaagaggaactcttgtcacgcgtatgactactacgegatcggcac }\end{array}$ & Left $\left(5^{\prime}\right)$ portion of artificial reaction control insert (Fig. 1) & This study \\
\hline Insert right arm & $\begin{array}{l}\text { gtgccgatcgegtagtagtcgaagaggacgactctagagtggagcccgaggca } \\
\text { gagcatcgctcagtacccaggcgecattgtagagcatgacgatccgg }\end{array}$ & Right ( $\left.3^{\prime}\right)$ portion of artificial reaction control insert (Fig. 1) & This study \\
\hline $50-2 \mathrm{~F}$ & cggagcgcgatagaagagga & Forward PCR primer for $\mathrm{Cms}^{\mathrm{a}}$ detection & 24 \\
\hline $133 \mathrm{R}$ & ggcagagcatcgctcagtacc & Reverse PCR primer for $\mathrm{Cms}$ detection & 24 \\
\hline $50-53 \mathrm{~T}$ & Cy5-aaggaagtcgtcggatgaagatgcg-Iowa Black RQ & Dual-labeled TaqMan probe for Cms detection & 24 \\
\hline M13R & caggaaacagctatgac & Forward primer for sequencing $\mathrm{pCmsC} 4$ insert & Unknown \\
\hline M13F(-20) & gtaaaacgacggccag & Reverse primer for sequencing $\mathrm{pCmsC} 4$ insert & Unknown \\
\hline
\end{tabular}

${ }^{a}$ Cms: primary diagnostic target Clavibacter michiganensis subsp. sepedonicus. 
evaluated for stability, expected insert size, and ability to generate the desired 240-bp fragment in the TaqMan assay. Plasmid $\mathrm{pCmsC4}$ was selected as the most suitable, and the insert fragment was sequenced by the Core Molecular Biology Facility of York University (Toronto, Canada) using primers M13F(-20) and M13R (Table 1).

For use as a reaction control in the TaqMan assay for $C$. michiganensis subsp. sepedonicus, $\mathrm{pCmsC4}$ was linearized with 0.4 units $/ \mu \mathrm{l} B g l \mathrm{II}$ (New England Biolabs). The linearized plasmid was quantified and stored as a $100 \times$ stock solution in $0.1 \times \mathrm{TE}$, $\mathrm{pH}$ 8.0. The number of copies per microliter was estimated from the mass concentration $(\mathrm{ng} / \mu \mathrm{l})$ according to the following formula:

Copies $/ \mu \mathrm{l}=(\mathrm{ng} / \mu \mathrm{l}) \times(\mathrm{nmol} / 650 \mathrm{ng} \mathrm{bp}) \times$ $1 / 4,215 \mathrm{bp} \times 6.02 \times 10^{14}$ copies $/ \mathrm{nmol}$

or

Copies $/ \mu \mathrm{l}=\mathrm{ng} / \mu \mathrm{l} \times 2.2 \times 10^{8}$

TaqMan assay for $C$. michiganensis subsp. sepedonicus. A previously published TaqMan assay (24) was optimized for the SmartCycler II (Cepheid, Sunnyvale, CA) fluorescence thermocycler. The reaction mix consisted of $1 \times$ SYBR Green JumpStart Taq ReadyMix (Sigma, St. Louis, $\mathrm{MO}$ ), and $0.2 \%$ BLOTTO to help counteract inhibitor effects (7). The forward and reverse primers, $50-2 \mathrm{~F}$ and $133 \mathrm{R}$, respectively, were used at a concentration of 0.3 $\mu \mathrm{M}$ each. The TaqMan probe 50-53T was labeled at the $5^{\prime}$ end with Cy5 and at the $3^{\prime}$ end with Iowa Black RQ, and was used at a concentration of $0.2 \mu \mathrm{M}$. Linearized reaction control plasmid pCmsC4 was also included in the reaction mix at a final concentration of 4 copies $/ \mu l$, or 100 copies per reaction. Two microliters of either sample template DNA, control DNA, or water (no template control) was also added. The reaction was carried out as follows: 1 cycle of 2 min at $95^{\circ} \mathrm{C}$, followed by 40 cycles of $15 \mathrm{~s}$ at $95^{\circ} \mathrm{C}$, and $60 \mathrm{~s}$ at $64^{\circ} \mathrm{C}$. Fluorescence was captured in the FAM and Cy5 channels during this step. The FAM channel was configured to excite and capture SYBR Green fluorescence, while the $\mathrm{Cy} 5$ channel was used to excite and capture $\mathrm{Cy} 5$ fluorescence. Following a final extension at $72^{\circ} \mathrm{C}$ for $3 \mathrm{~min}$, melt curves were generated using the default settings.

The cycle threshold $(\mathrm{Ct})$, the cycle at which the fluorescence rose significantly

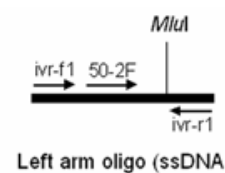

$100 \mathrm{bp}$

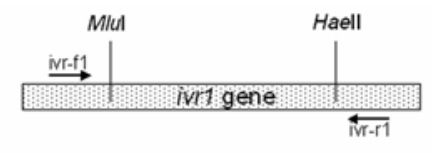

Corn extract

$\downarrow$

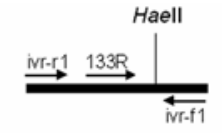

Right arm oligo (sSDNA)
Amplify fragments in PCR with ivr-f1 and ivr-r1 and gel purify

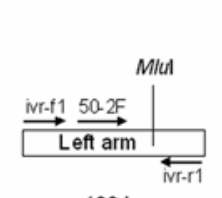

$100 \mathrm{bp}$

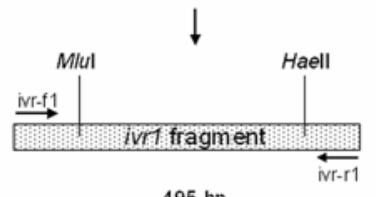

495 bp

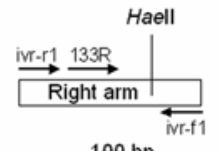

$100 \mathrm{bp}$ $\downarrow$

Digest fragments with Mlul and Haell and gel purify

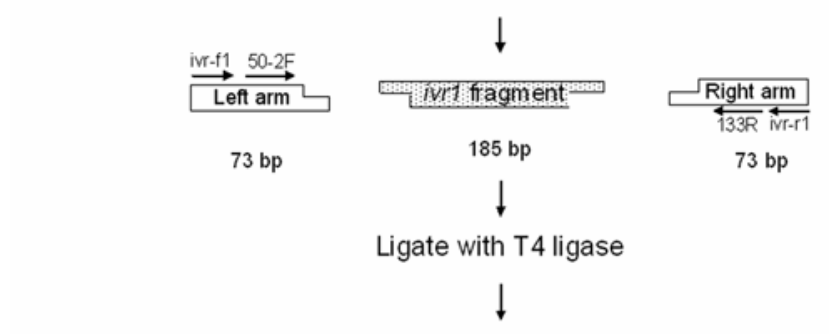

Amplify desired fragment in PCR using $\mathrm{Cms}$ - specific primers $50-2 \mathrm{~F}$ and $133 \mathrm{R}$ and gel purify

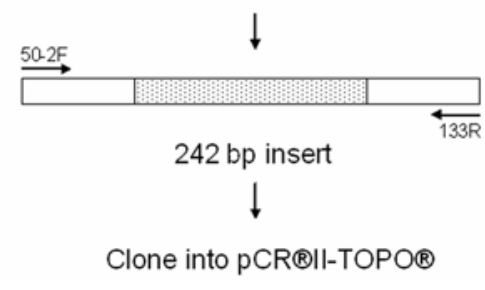

Fig. 1. Strategy used to construct the artificial reaction control plasmid pCmsC4. above background, was arbitrarily set at fluorescence values of 15 and 4 for the FAM and Cy5 channels, respectively, to facilitate between-run comparisons. Reaction efficiencies were determined by measuring the slope of the regression line generated by $\mathrm{Ct}$ value versus the log of the target concentration. Efficiency (E) was calculated as:

$E=1-10^{1 / \text {-slope }}$

Selected samples were also analyzed by gel electrophoresis in $2 \%$ agarose to evaluate PCR products. The agarose gels contained $0.5 \mu \mathrm{g} / \mathrm{ml}$ ethidium bromide (Invitrogen), and were prepared and run in $0.5 \times$ TBE (45 mM Tris, $45 \mathrm{mM}$ boric acid, 1 mM EDTA). Digital images of the gels were viewed and captured using the GeneGenius BioImaging system (Syngene, Cambridge, UK).

Effect of inhibitors on reaction control performance. Either humic acid (technical grade, Sigma) or guanidine hydrochloride (Sigma) was added at varying concentrations to the TaqMan assay. Templates for the assay were derived from samples that contained the equivalent of 0 , $5 \times 10^{3}$, or $5 \times 10^{4}$ cells $/ \mathrm{ml}$ of homogenate. The effect of the inhibitors on the reaction control plasmid pCmsC4 amplification and on C. michiganensis subsp. sepedonicus detection was determined by measuring the change of $\mathrm{Ct}(\Delta \mathrm{Ct})$ in the FAM and Cy5 channel, respectively, with and without the inhibitor.

Serological detection. C. michiganensis subsp. sepedonicus was detected using a triple antibody sandwich (TAS)-ELISA that utilized monoclonal antibody $1 \mathrm{H} 3$ as the primary detection antibody. Samples generating positive results in ELISA were also tested with IMF utilizing monoclonal antibody 9A1. Both methods were carried out according to standard protocols described in detail elsewhere $(6,8,9)$. The threshold for IMF was 150 fluorescing cells/30 microscope fields, while the thresholds for the ELISA tests were calculated from positive and negative control values as previously described (4).

Statistical analyses. The D'Agostino and Pearson omnibus normality test was used to determine Gaussian goodness-offit for the frequency distributions. Grubbs' test was used to detect outliers, and was performed using an online calculator developed by GraphPad Software (San Diego, CA). All regression and statistical analyses, except Grubbs' test, were performed using GraphPad Prism version 4.03 (GraphPad Software).

\section{RESULTS AND DISCUSSION}

Analysis of pCmsC4. The reaction control plasmid, pCmsC4, contained a 242-bp insert sequence in forward orientation, and was flanked at the $5^{\prime}$ and $3^{\prime}$ ends by $C$. michiganensis subsp. sepedonicus-specific primer sequences 50-2F and 133R, respec- 
tively (Fig. 2). The HaeII restriction site was retained in the insert, whereas the MluI site was lost in the ligation. The insert had a GC content of $73 \%$.

The $\mathrm{pCmsC4}$ insert sequence was amplified in the TaqMan assay using the primer pair $50-2 \mathrm{~F}$ and $133 \mathrm{R}$. The 242-bp reaction control amplicon was easily distinguishable from the 152-bp C. michiganensis subsp. sepedonicus-specific product in agarose electrophoresis (Fig. 3A). Addition of SYBR Green to the reaction mix allowed the identification of both products based on their melting profiles. The $C$. michiganensis subsp. sepedonicusspecific target amplicon, generated using a DNA extract from a pure culture of $C$. michiganensis subsp. sepedonicus, had a melting temperature of about $85^{\circ} \mathrm{C}$; while the pCmsC4 reaction control amplicon, generated using $\mathrm{pCmsC} 4$ as template, had a melting temperature of approximately $94^{\circ} \mathrm{C}$ (Fig. 3B).

The SYBR Green (FAM Channel) Cts generated with the $\mathrm{pCmsC4}$ template were inversely proportional to the log concentration of the plasmid DNA in the reaction (Fig. 4A), and the regression line had a correlation coefficient $>0.99$. This was the expected result, as it reflected the exponential nature of the amplification reaction. The slope of the regression line (Fig. 4A) was $-3.801 \pm 0.054$, and on this basis the amplification efficiency of the $\mathrm{pCmsC4}$ insert sequence in the TaqMan assay was calculated to be $83.2 \%$.

Effect of reaction control on the TaqMan assay. DNA extracted from homogenates of healthy tuber tissue, to which had been added different concentrations of a pure culture of $C$. michiganensis subsp. sepedonicus from a 10-fold dilution series $\left(10^{4}\right.$ to $\left.10^{8} \mathrm{CFU} / \mathrm{ml}\right)$, was used as the sample template in the TaqMan assay with and without the addition of 100 copies of linearized $\mathrm{pCmsC} 4$ per reaction. The Cy5 Cts generated from the TaqMan probe, with or without the reaction control, were very similar at each concentration of C. michiganensis subsp. sepedonicus (Fig. 4B). The regression lines generated with 0 and 100 copies of pCmsC4 per reaction were almost identical, with slopes of -3.55 $\pm 0.12\left(r^{2}=0.99\right)$ and $-3.48 \pm 0.14\left(r^{2}=\right.$ 0.99), respectively (Fig. 4B). Analysis of covariance indicated that there was no significant difference between the two slopes $(F(1,16 \mathrm{df})=0.147 ; P=0.71)$. This demonstrated that the addition of 100 copies per reaction of $\mathrm{pCmsC} 4$ to the TaqMan assay did not affect the reaction efficiency, and was a strong indication that the addition of $\mathrm{pCmC4}$ did not affect the sensitivity of the TaqMan assay. The mean efficiency of $C$. michiganensis subsp. sepedonicus target amplification calculated from the pooled slopes $(-3.515)$ was $92.5 \%$.

The limit of reliable detection of this TaqMan method was previously estimated at approximately $2-4 \times 10^{3}$ cells $/ \mathrm{ml}$ homogenate (unpublished data). To test whether addition of the internal reaction control had an effect on the detection limit, a pure culture of $C$. michiganensis subsp. sepedonicus was spiked into healthy potato tuber homogenates at $10^{3} \mathrm{CFU} / \mathrm{ml}$, a concentration just below the reliable limit of detection. The spiked homogenates were extracted and analyzed for $C$. michiganensis subsp. sepedonicus using the TaqMan assay with either 0 or 100 copies of $\mathrm{pCmsC4}$ in each reaction. The range of $\mathrm{Cts}$ obtained in the presence of 100 copies of pCmsC4 was 35.77 to 37.21 , which was slightly higher than the range of Cts (34.09 to 36.13) obtained with no $\mathrm{pCmsC4}$ present (Table 2). In the absence of the pCmsC4 reaction control, however, $C$. michiganensis subsp. sepedonicus was detected in the extracts in 3 out of 7 analyses; while in the presence of 100 copies of $\mathrm{pCmsC4}, C$. michiganensis subsp. sepedonicus was detected in the extracts in 4 of 7 analyses (Table 2).

The stochastic nature of these results is often observed in PCR when target concentration in the extract is very low, and reflects the sampling error inherent in capturing the target template from the extract in a small subsampled volume for PCR analysis. The fact that there was little difference in the overall detection rate, with or without $\mathrm{pCmsC4}$, supported the conclusion drawn from the data presented in Figure 4B; i.e., that the reaction control did not effectively compete with the primary diagnostic target in PCR, and ultimately had no adverse effect on the detection of C. michiganensis subsp. sepedonicus.

To evaluate the effect of $\mathrm{pCmsC4}$ on the specificity of the TaqMan assay, 28 known positive and 50 known negative samples were analyzed for $C$. michiganensis subsp. sepedonicus in the presence of 100 copies of $\mathrm{pCmsC4/reaction.} \mathrm{All} 28$ positive samples generated positive results, while the 50 negative samples all returned negative results (Table 3). The reaction control plasmid $\mathrm{pCmsC4}$, therefore, had no effect on the specificity of the TaqMan assay.

Result confirmation: defining amplicon melting temperature tolerances. Figure 3B demonstrated that the amplicons generated from the primary $C$. michiganensis subsp. sepedonicus target and the reaction control $\mathrm{pCmsC} 4$ could be easily distinguished by their melting temperature profiles. In order to use melting temperatures for confirming amplicon identity in a diagnostic application, temperature tolerances, or the range of acceptable melt peak temperatures, had to be established. In the case of both the positive and negative results, the accepted temperature range to confirm the presence of the correct ampli-

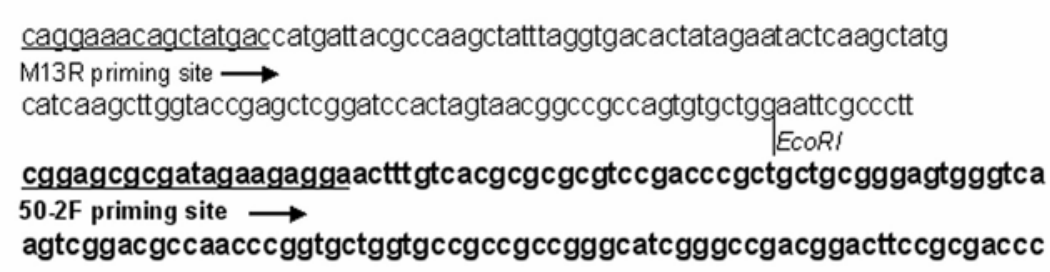

gacgacggcgtggcggacgcccggcaacgacacgccggcgtggegggtcgccatcgggtccaa

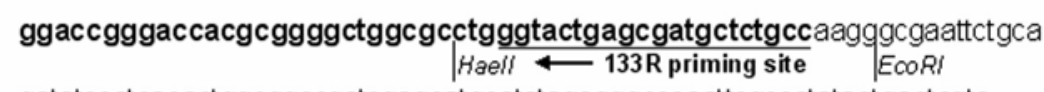

gatatccatcacactggcggccgctcgagcatgcatctagagggcccaattcgccctatagtgagtcgta

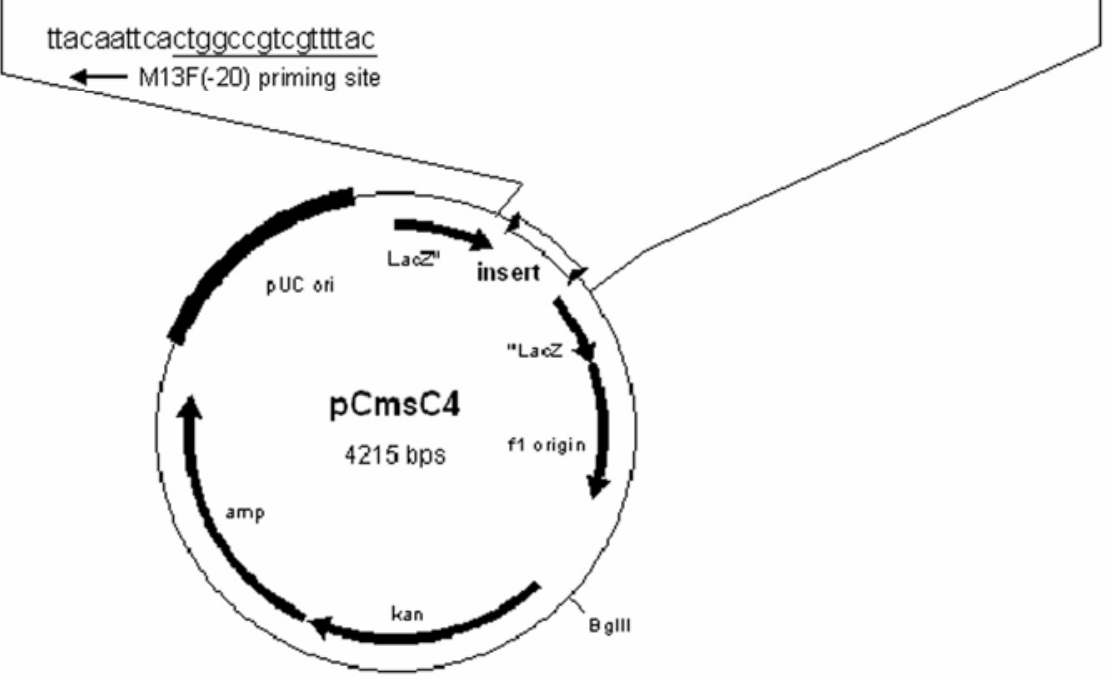

Fig. 2. Map and partial sequence of reaction control plasmid $\mathrm{pCmsC4}$. Regular face type indicates the vector sequence while bold face type indicates the insert sequence. Primer binding sites are underlined. 
con was defined as the range of temperatures that would include $99 \%$ of all true positive or negative results, i.e., the mean plus or minus 2.576 times the standard deviation. This is based on the fact that $1.00 \%$ of a standard two-tailed Gaussian distribution has $Z$ values greater than 2.576 or less than -2.576 , with $Z=1$ standard deviation around the mean of the distribution.

Melt peaks generated by the 27 positive samples fit a normal distribution $(P=0.94$; Fig. 5A), with a mean of $85.50^{\circ} \mathrm{C}$ and a standard deviation of $0.15^{\circ} \mathrm{C}$. One outlier was detected (Fig. 5A). The accepted temperature range to confirm the presence of the C. michiganensis subsp. sepedonicusspecific 152-bp amplicon was therefore 85.11 to $85.89^{\circ} \mathrm{C}$.

Of the 50 negative samples, 47 generated detectable melt peaks for the $\mathrm{pCmsC4}$ reaction control amplicon (Table 3), and these, along with data from an additional 13 negative samples, were used to generated a frequency distribution histogram for the reaction control amplicon melt peak temperature (Fig. 5B). This data also fit a normal distribution $(P=0.32)$ with a mean melt peak temperature of $94.53^{\circ} \mathrm{C}$ and a standard deviation of $0.13^{\circ} \mathrm{C}$. The accepted temperature range for the identification of the $\mathrm{pCmsC} 4$ reaction control amplicon was therefore 94.20 to $94.86^{\circ} \mathrm{C}$.

Detecting reaction inhibitors. The main purpose of including a reaction control in a PCR analysis is to detect any potential inhibitors that may invalidate negative results. Experiments were performed in order to determine whether pCmsC4 was effective in indicating the presence of inhibitors or reaction failure in the TaqMan assay. Addition of either humic acid or guanidine hydrochloride increased the $\mathrm{Cts}$ generated by both $\mathrm{pCmsC} 4$ and the $C$. michiganensis subsp. sepedonicus target in a concentration-dependent manner (Fig. 6), indicating that these substances had an inhibitory effect on the amplification of both targets. The plateaus of the curves at the higher concentrations indicated that the Cts could not increase further, as the reaction was completely inhibited (Fig. 6).

For humic acid, $0.25 \mu \mathrm{g} / \mathrm{ml}$ was sufficient to increase the $\mathrm{Ct}$ of the $\mathrm{pCmsC4} \mathrm{RC}$ by 8 cycles, while the $\mathrm{Ct}$ generated by the C. michiganensis subsp. sepedonicus target at either $5 \times 10^{3}$ or $5 \times 10^{4}$ cells $/ \mathrm{ml}$ increased by a little more than 1 cycle (Fig. $6 \mathrm{~A})$. The addition of $0.3 \mu \mathrm{g} / \mathrm{ml}$ humic acid increased the $\mathrm{pCmsC4} \mathrm{RC} \mathrm{Ct}$ by more than 10 cycles, completely inhibiting the reaction, while increasing the Cts generated by the $C$. michiganensis subsp. sepedonicus target by only about 2 cycles. The addition of more than $0.4 \mu \mathrm{g} / \mathrm{ml}$ humic acid was required to completely inhibit the amplification of the $C$. michiganensis subsp. sepedonicus target and generate a false negative result.

Guanidine hydrochloride at $11 \mathrm{mM}$ increased the pCmsC4 $\mathrm{Ct}$ by about 7 cycles
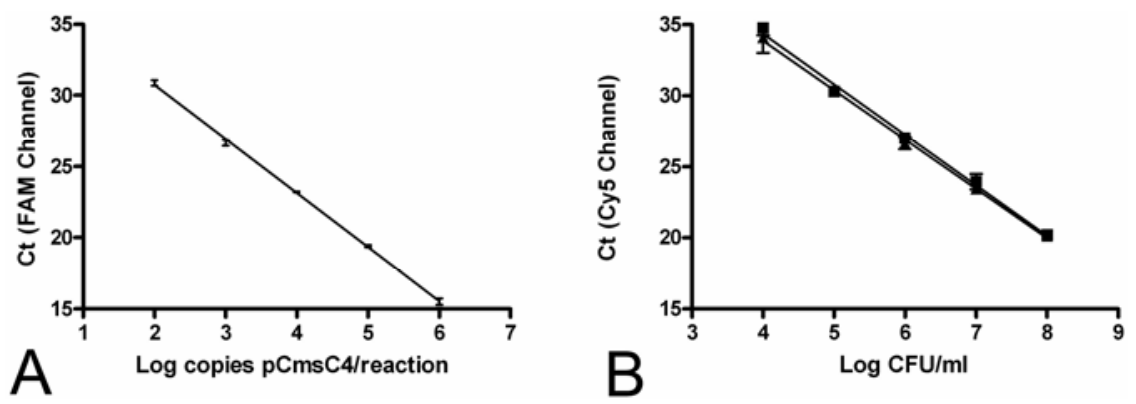

Fig. 4. Cycle thresholds (Cts) generated in the (A) FAM channel as a function of the concentration of $\mathrm{pCmsC4}$ and in the (B) Cy5 channel as a function of the concentration of the primary assay target, Clavibacter michiganensis subsp. sepedonicus, with $0(\mathbf{\square})$ and $100(\boldsymbol{\Delta})$ copies of pCmsC4 added per reaction. Error bars represent the standard deviation around the mean of duplicate observations $(\mathbf{B})$ in two runs (A).

Table 2. Detection of very low levels $\left(\mathrm{ca} .10^{3} \mathrm{CFU} / \mathrm{ml}^{\mathrm{a}}\right.$ ) of Clavibacter michiganensis subsp. sepedonicus in various extracts, with and without the positive reaction control $\mathrm{pCmsC} 4$ spike

\begin{tabular}{lcc}
\hline & \multicolumn{2}{c}{ Ct in Cy5 Channel } \\
\cline { 2 - 3 } Extract & 0 copies pCmsC4/reaction & $\mathbf{1 0 0}$ copies $\mathbf{~ C m s C 4 / r e a c t i o n ~}$ \\
\hline 1 & $>40$ (not detected) & 35.32 \\
2 & 36.02 & 37.21 \\
3 & $>40$ (not detected) & $>40$ (not detected) \\
4 & $>40$ (not detected) & $>40$ (not detected) \\
5 & $>40$ (not detected) & 36.26 \\
$6 \mathrm{a}^{\mathrm{b}}$ & 36.13 & 35.11 \\
$6 \mathrm{~b}^{\mathrm{b}}$ & 34.09 & $>40$ (not detected) \\
Positive control & 17.09 & 17.33 \\
No template control & $>40$ (not detected) & $>40$ (not detected) \\
\hline
\end{tabular}

a Below the reliable limit of detection.

${ }^{\mathrm{b}}$ Duplicate observations with the same extract.

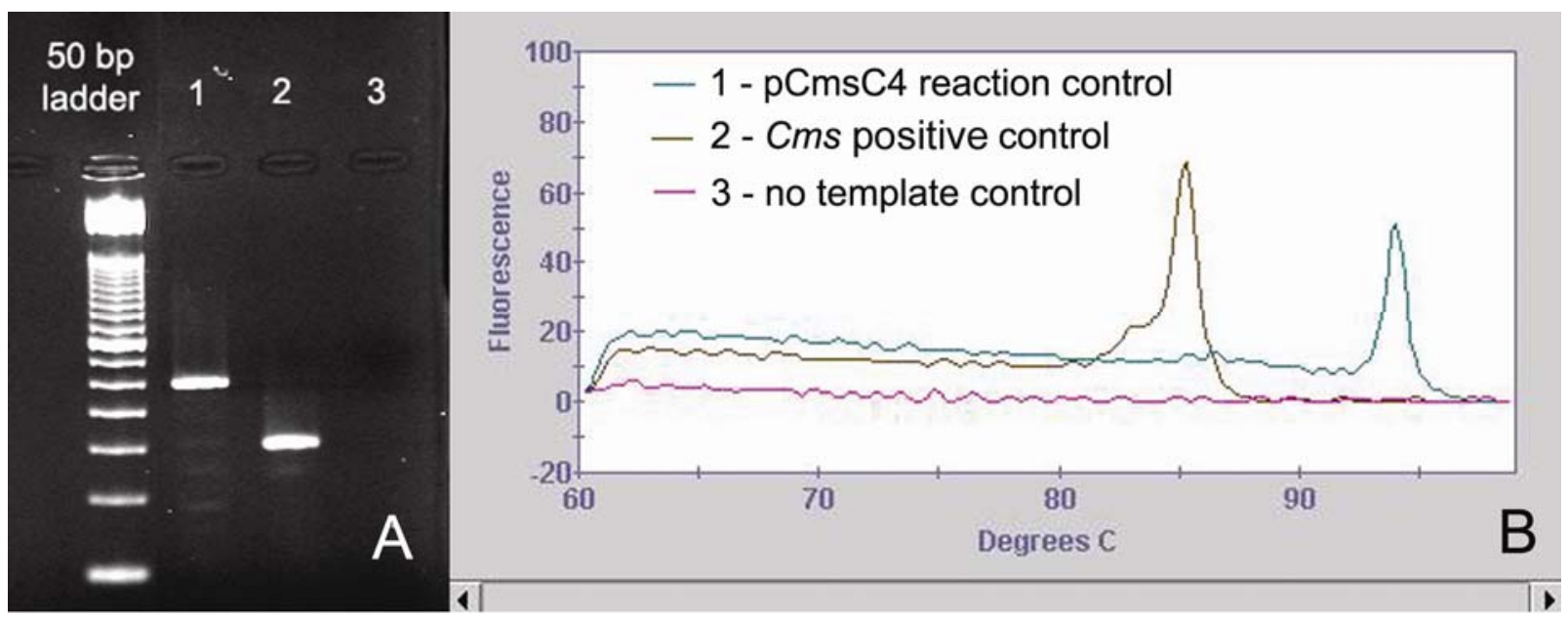

Fig. 3. Characterization of amplicons produced in real-time polymerase chain reaction (PCR) with the following templates: (1) pCmsC4 reaction control; (2) DNA extract from a pure culture of Clavibacter michiganensis subsp. sepedonicus (Cms); (3) nuclease-free water (no template control) in A, 2\% agarose electrophoresis and B, SYBR Green fluorescence melt curve analysis. 
(Fig. 6B). This concentration had only a slight effect on the $\mathrm{Ct}$ generated by the low concentration of $C$. michiganensis subsp. sepedonicus target and no effect on the $\mathrm{Ct}$ generated with $5 \times 10^{4}$ cells $/ \mathrm{ml} \mathrm{C}$. michiganensis subsp. sepedonicus (Fig. 6B). The addition of $12.5 \mathrm{mM}$ guanidine hydrochloride was sufficient to completely inhibit pCmsC4 RC amplification (Fig. 6B). This concentration resulted in some inhibition at $5 \times 10^{3}$ cells $/ \mathrm{ml}$, but had no detectable effect on amplification at $5 \times 10^{4}$ cells/ml (Fig. 6B). To completely abolish C. michiganensis subsp. sepedonicus detection at $5 \times 10^{3}$ cells $/ \mathrm{ml}$ and $5 \times 10^{4}$ cells $/ \mathrm{ml}, 15 \mathrm{mM}$ and $25 \mathrm{mM}$ guanidine hydrochloride were required, respectively.

These experiments demonstrated that the two different inhibitors affected the $\mathrm{Ct}$ of the $\mathrm{pCmsC} 4$ reaction control at concentrations lower than those required to observe the same effect on the $\mathrm{Ct}$ of the $C$. michiganensis subsp. sepedonicus target. Inhibition is, therefore, unlikely to produce a false negative result for $C$. michiganensis subsp. sepedonicus without either abolishing pCmsC4 amplification, or at least increasing the $\mathrm{Ct}$ generated in the FAM channel by $\mathrm{pCmsC4}$.

Determination of a quantitative threshold for inhibitor detection. For the validation of negative results in routine analysis, a threshold for the maximum acceptable $\mathrm{Ct}$ generated by the $\mathrm{pCmsC4}$ reaction control had to be established. The FAM channel Cts produced by the $C$. $m i$ chiganensis subsp. sepedonicus-negative samples were plotted as a frequency histogram (Fig. 7). The data approximated a normal distribution $(P=0.067)$, with a mean $\mathrm{Ct}$ of 31.33 and a standard deviation of 0.65 . Three Grubbs' outliers $(P<0.05)$ were detected with Cts 33.41, 35.07, and 37.04 (Fig. 7). The other Cts obtained ranged between 29.44 and 32.34-wider than expected considering that each $\mathrm{Ct}$ was generated with the same concentration of $\mathrm{pCmsC} 4$ template. This observed range was skewed toward the lower Cts, and may have been the consequence of products amplified in spurious, nonspecific side reactions. This would have contributed to an increase in the overall SYBR Green fluorescence in some of the samples, thus lowering the $\mathrm{Ct}$ value obtained.

The maximum $\mathrm{Ct}$ acceptable for validation of negative results was set as the value that would likely be greater than $99 \%$ of all $\mathrm{Cts}$ generated by $\mathrm{pCmsC4}$ in negative samples in the absence of inhibitors. In other words, $99 \%$ of $\mathrm{Ct}$ values obtained in valid reactions generating negative results for $C$. michiganensis subsp. sepedonicus would likely be less than this threshold. Since $99 \%$ of a one-tailed Gaussian distribution have values less than 2.326 standard deviations above the mean, the maximum acceptable $\mathrm{Ct}$ value was the mean (31.33) plus 2.326 times the standard deviation (0.65); or 32.84 . Valid negative results, therefore, would have to generate $\mathrm{Ct}$ values less than 32.84 .

Performance with diagnostic samples. In addition to the samples previously examined (Table 3), another set of 234 diagnostic samples was analyzed using the TaqMan assay. Of these, 71 were first used to compare fluorescence signal in real-time PCR with visualization of amplicons by agarose electrophoresis as in conventional PCR. Out of 28 of these samples that generated a Cy 5 signal, all but 2 generated an $85.5^{\circ} \mathrm{C}$ melt peak, and all but one generated a 152-bp band in agarose electrophoresis. For one of the inconsistent samples, only the $94.5^{\circ} \mathrm{C}$ melt peak was observed even though both bands were visible in agarose electrophoresis, while the other inconsistent sample had a very high $\mathrm{Ct}$ of 39.73 in the Cy5 channel, no melt peak, and the 152-bp band was not visible in agarose electrophoresis. These two samples might be considered weak or unconfirmed positives, as the identity of the fluorescence signal could not be confirmed by melt peak analysis. Overall, however, the results show that the fluorescence signal plus melt peak analysis of the PCR results correlated very well with the result obtained by agarose electrophoresis (Fig. 8).

The remaining 43 samples of this group tested negative in PCR and did not yield the 152-bp amplicon in agarose electrophoresis. All except five of these samples had FAM Cts lower than the upper threshold of 32.84 , melt peaks within the acceptable range of 94.20 to $94.86^{\circ} \mathrm{C}$, and the 242-bp reaction control amplicon was visualized in agarose electrophoresis (Fig. 8). Four of the five inconsistent samples had melt peaks outside the acceptable range but displayed the 242-bp band, suggesting that the acceptable melt peak temperature range may be overly stringent. One sample did not produce an FAM signal and only a weak 242-bp band in agarose electrophoresis, which suggested the presence of inhibitory substances.

The serological test results for the entire 234 sample set were compared with the results obtained in the TaqMan PCR assay (Fig. 9). All 13 samples in this data set that were clearly positive by ELISA and IMF were also clearly positive in the real-time TaqMan PCR assay. However, of the 96 samples that were ELISA-positive but IMF-negative (i.e., with $<150$ fluorescing cells/30 microscope fields), slightly less than half (47 samples) were positive by PCR and were confirmed with the appropriate melting peak. Forty of these 96 samples were negative in PCR and confirmed as such by the $\mathrm{Ct}$ and melting peak of the internal reaction control. Another

Table 3. Effect of pCmsC4 (100 copies/reaction) on the specificity of the TaqMan detection method for Clavibacter michiganensis subsp. sepedonicus

\begin{tabular}{|c|c|c|c|c|c|c|c|}
\hline & \multirow{2}{*}{$\begin{array}{l}\text { Number } \\
\text { tested }\end{array}$} & \multicolumn{3}{|c|}{ Positive results } & \multicolumn{3}{|c|}{ Negative results } \\
\hline & & Total & Confirmed $^{\mathrm{a}}$ & 152 bp $^{\mathrm{b}}$ & Total & Validated $^{c}$ & Confirmed $^{\mathrm{a}}$ \\
\hline $\begin{array}{l}\text { Positive } \\
\text { samples }^{\mathrm{d}}\end{array}$ & 28 & 28 & 27 & 28 & 0 & $\mathrm{n} / \mathrm{a}^{\mathrm{e}}$ & $\mathrm{n} / \mathrm{a}$ \\
\hline $\begin{array}{l}\text { Negative } \\
\text { samples }^{\mathrm{f}}\end{array}$ & 50 & 0 & $\mathrm{n} / \mathrm{a}$ & $\mathrm{n} / \mathrm{a}$ & 50 & 47 & 47 \\
\hline
\end{tabular}

${ }^{a}$ Result confirmed with melt temperature of amplification product 85.1 to $85.9^{\circ} \mathrm{C}$ for positive results and 94.20 to $94.86^{\circ} \mathrm{C}$ for negative results.

b 152 bp refers to molecular size of amplicon generated by the Clavibacter michiganensis subsp. sepedonicus target.

${ }^{\mathrm{c}}$ Result validated with the FAM Channel cycle threshold $(\mathrm{Ct}) \leq 32.84$.

d Samples had previously tested positive in enzyme-linked immunosorbent assay (ELISA) and immunofluorescence microscopy.

${ }^{\text {e }}$ Not applicable.

${ }^{\mathrm{f}}$ Samples had been sourced from farm units with no prior history of Clavibacter michiganensis subsp. sepedonicus infection; tested negative in ELISA.
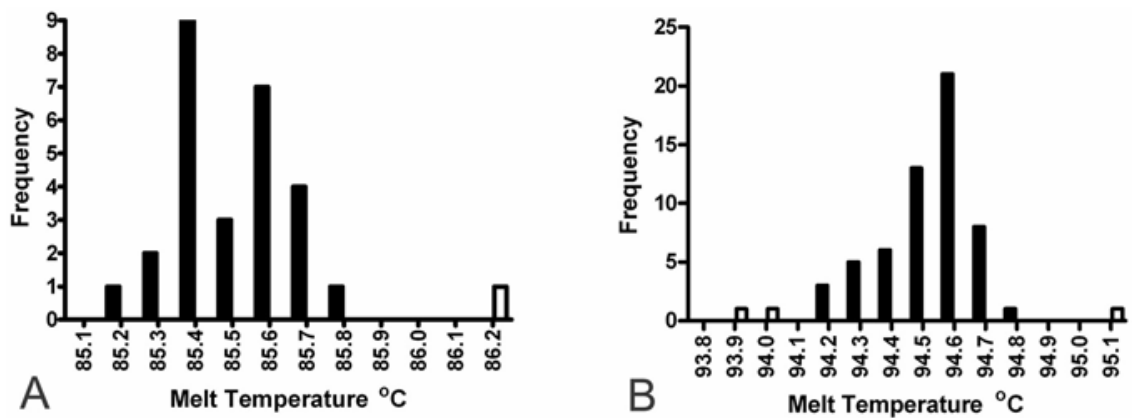

Fig. 5. Frequency histograms of melt peak temperatures of amplicons generated with the Clavibacter michiganensis subsp. sepedonicus primary target $(n=28 ; \mathbf{A})$ and the $\mathrm{pCmsC} 4$ reaction control $(n=60$; B) template DNAs. Measurements falling within the normal distribution of each data set are displayed as black bars, while Grubbs' outliers $(P<0.05)$ are displayed as white bars. 

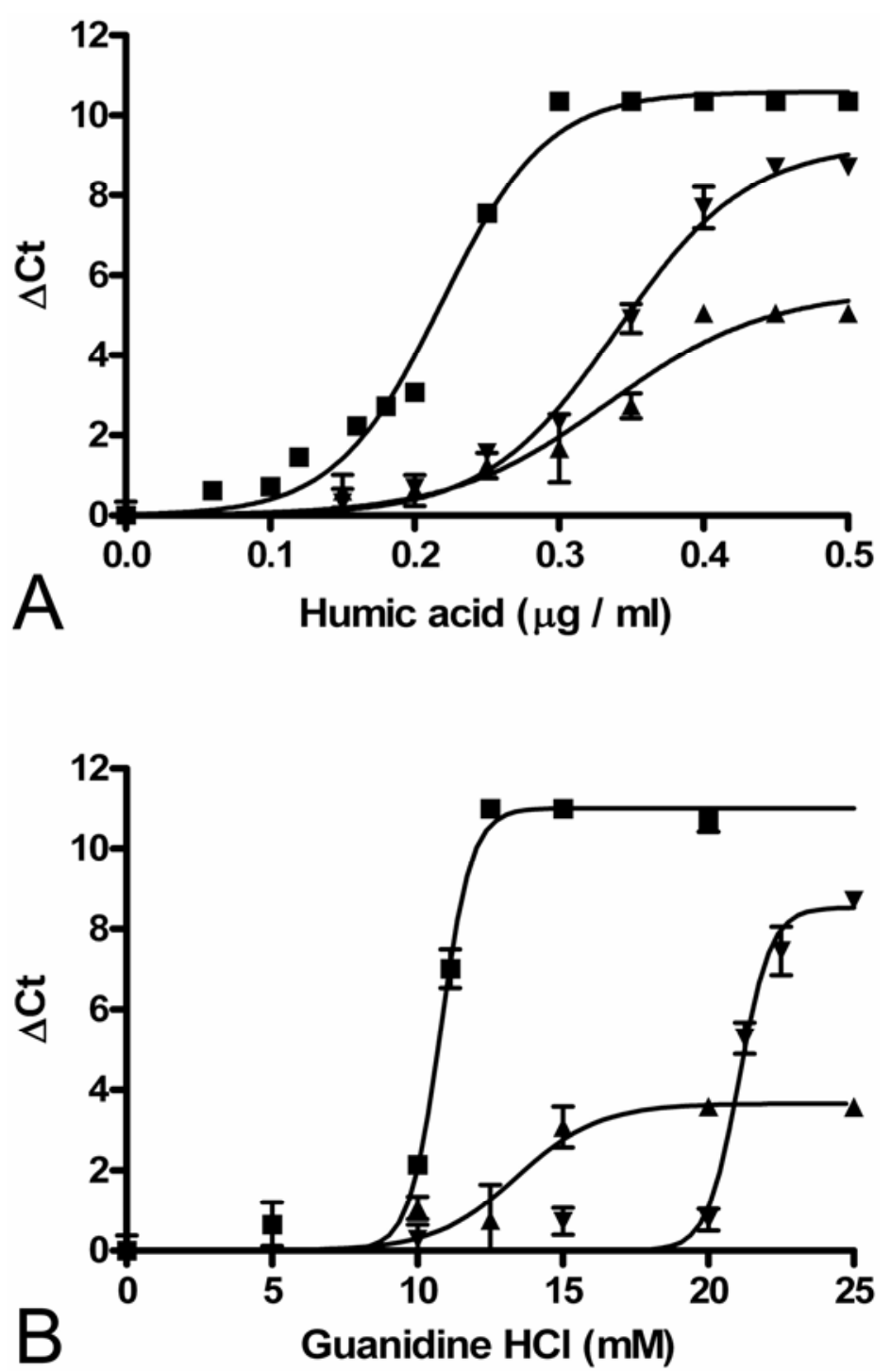

Fig. 6. Effect of humic acid (A) and guanidine hydrochloride (B) concentration on the change in cycle threshold $(\mathrm{Ct})$ generated by the pCmsC4 reaction control $(\mathbf{\square})$ and the $\mathrm{Cts}$ generated by $5 \times 10^{4}(\boldsymbol{\nabla})$ and $5 \times 10^{3}(\mathbf{\Delta}) \mathrm{CFU}$ of Clavibacter michiganensis subsp. sepedonicus per $\mathrm{ml}$ of homogenate. Error bars represent the standard deviation around the mean of triplicate measurements.

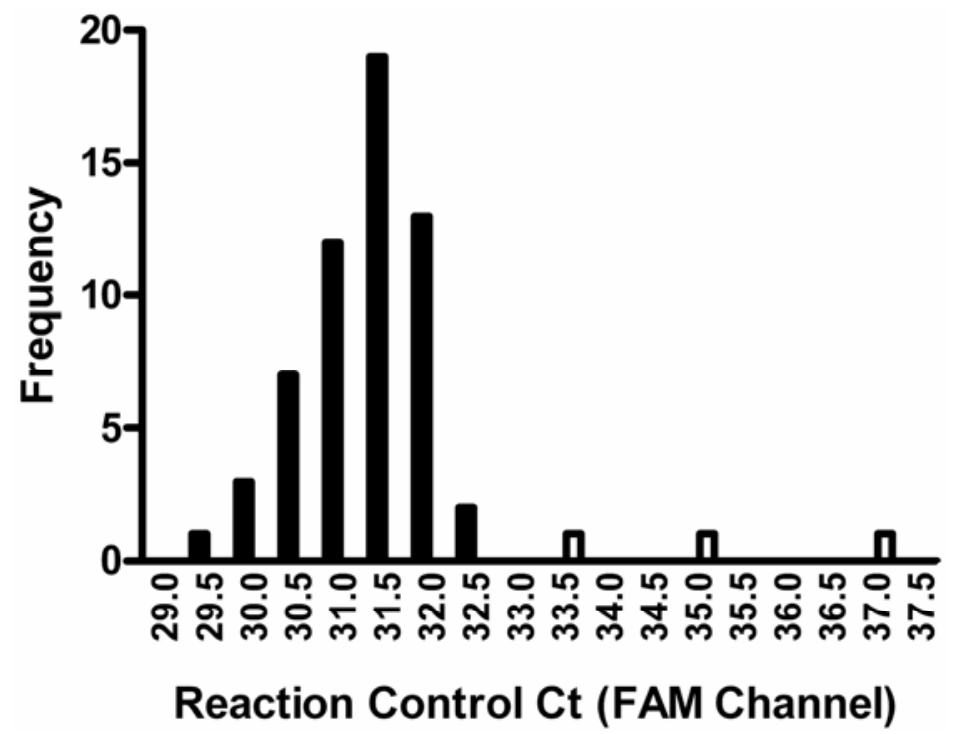

Fig. 7. Frequency histogram of FAM Channel cycle thresholds (Cts) generated by pCmsC4 in known negative samples $(n=60)$ with the TaqMan assay. Black bars represent data fitting a Gaussian distribution. White bars represent Grubbs' outliers $(P<0.05)$. four ELISA-positive but IMF-negative samples also produced a Cy5 signal but produced inadequate amplicon to permit melt peak analysis. The latter results suggest a weak positive result, as confirmation was not achieved. In addition, 5 samples with no signal in the Cy5 channel generated elevated $\mathrm{Cts}$ in the FAM channel, indicating an invalid negative result. These 5 samples were flagged as potentially containing PCR inhibitors.

Of the 125 ELISA-negative samples in this data set, 88 samples were negative by PCR, and the absence of inhibitors was confirmed by the FAM signal and melt peak of the reaction control amplicon. In another 12 samples, the $\mathrm{Ct}$ of the FAM signal was either higher than the maximum acceptable $\mathrm{Ct}$ value that had been set ( 9 samples) or did not generate melting peaks within the acceptable melt parameters ( 3 samples), thus generating an invalid negative result. The 9 samples were also flagged as containing PCR-inhibiting substances. Twenty-five of the 125 ELISAnegative samples were positive in the PCR test for C. michiganensis subsp. sepedonicus and confirmed by melt peak analysis for 20 of them (Fig. 9). The 5 samples that could not be confirmed by melt peak analysis produced inadequate amplicon for the analysis, probably because of a low amount of template DNA from low level infections with $C$. michiganensis subsp. sepedonicus.

The 14 samples that generated invalid negative results, and were flagged as containing PCR-inhibiting substances, were re-extracted to further purify the DNA. A second PCR test on 13 of these samples yielded the expected reaction control fluorescence signal and melt peak confirmation. The 14th sample, however, required a further 1:10 dilution to obtain a reaction control signal. This sample was also confirmed negative.

It should be noted that the samples in this data set do not represent the overall population because the lots were not sampled randomly. While some of the samples were from production units that have never had ring rot, the majority were selected from lots requiring supplementary testing because of their association with a ring rot positive farm unit, or had generated inconclusive results upon initial testing by the standard method. While 47 more samples were found to be positive by the real-time TaqMan PCR procedure than by the serological procedures for this particular sample set, many of the ELISA-positive, IMFnegative samples did contain fluorescing cells. These were rated negative for IMF because the numbers of fluorescing cells were below the established threshold (4). In routine testing, detecting fluorescing cells below the established threshold would have triggered additional testing and possibly re-sampling to avoid false positive diagnoses and their associated regulatory 
and financial impacts. The greater sensitivity attained by PCR compared with the serological test is apparent from the $8.5 \%$ of samples in this sample set that were ELISA-negative but PCR-positive. Nevertheless, this was likely an overestimation of the actual proportion of positive samples that are typically undetected in ELISA because of the nonrandom selection of the sample set.

The ELISA method is well suited to large-scale screening. It is economical, simple to perform, and facilitates a high sample throughput. While less sensitive than PCR, the results of this study have suggested that only a small percentage of positive samples are undetected in ELISA, even in a positive-biased population. In seed potato certification, the impact of these potentially undetected samples can be offset by utilizing strategic sampling regimes, and targeting higher risk areas and suspect tuber lots with more intensive sampling and screening. Unless it becomes economically feasible, it is unlikely that PCR will replace ELISA as the primary screening method for C. michiganensis subsp. sepedonicus infection in seed pota-

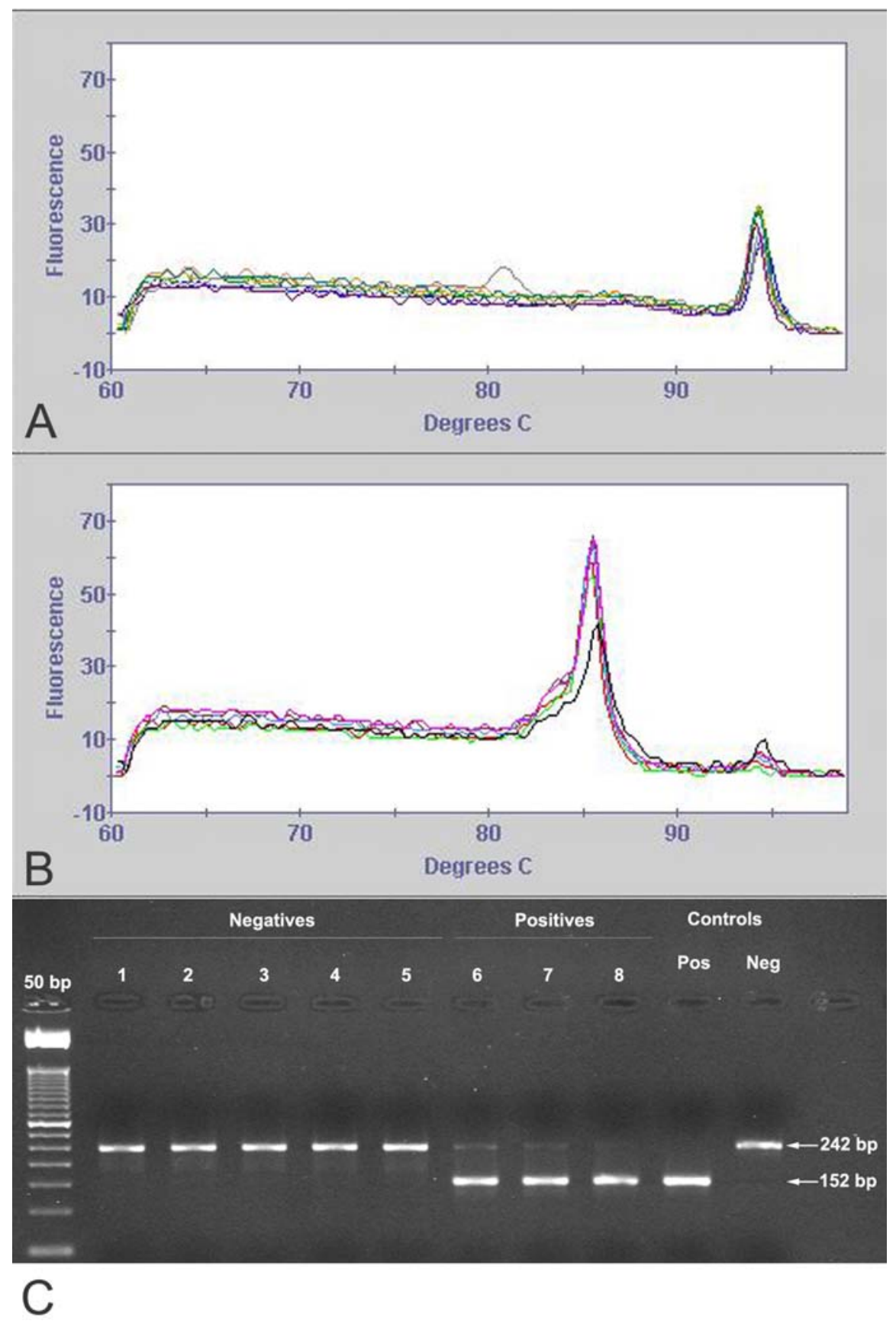

Fig. 8. Typical melting profiles of negative (A) and positive (B) diagnostic samples, and their correlation with the appearance of 242- and 152-bp bands in agarose electrophoresis, respectively (C). C, $50 \mathrm{bp}, 50$-bp ladder molecular size standard; lanes 1 to 5, negative samples generating a 242-bp amplicon and a ca. $94.5^{\circ} \mathrm{C}$ melting peak (A); lanes 6 to 8, positive samples generating a 152-bp amplicon and a ca. $85.5^{\circ} \mathrm{C}$ melt peak (B). Pos, positive control; Neg, negative control. toes in the near future. This PCR method does have considerable promise, however, as a confirmatory method to replace or supplement IMF.

In summary, it is concluded that including an internal reaction control in the real-time PCR TaqMan assay for the detection of $C$. michiganensis subsp. sepedonicus provides a means of detecting false negative results that may arise as a consequence of reaction failure. Our reaction control consisted of a sequence unrelated to the primary $C$. michiganensis subsp. sepedonicus target, flanked by primer sequences designed to specifically detect $C$. michiganensis subsp. sepedonicus in a TaqMan assay. This type of reaction control has been used previously in the conventional PCR methods for the detection of Erwinia carotovora subsp. atroseptica (13), Agrobacterium tumefaciens (3), and C. michiganensis subsp. sepedonicus (12).

In a PCR reaction, the inclusion of a secondary DNA sequence containing the same primer binding sites as the primary target could potentially create unwanted competition for the primers and other reaction components, and thereby reduce the sensitivity of the PCR method for the desired primary target. In addition, nonspecific side reactions may produce false results, or further reduce the efficiency of the primary reaction. It was demonstrated, however, that the reaction control pCmsC4, used at 100 copies/reaction, had no deleterious effects on either the sensitivity or the specificity of the TaqMan assay. The amplification efficiency of the reaction control was lower than that of the primary target. This was probably attributable to the high GC content of the reaction control, and indicated that the amplification of the reaction control would be very unlikely to compete effectively with the amplification of the primary diagnostic target.

Finally, by setting specific $\mathrm{Ct}$ and melt peak criteria as positive/negative thresholds for detection of the $C$. michiganensis subsp. sepedonicus target and the reaction control, test results could be objectively categorized as confirmed positive, confirmed negative, or requiring additional work. Obviating the need for subjective interpretation of test results by setting of specific threshold values is particularly important for diagnostic laboratories that operate within a quality assurance program.

\section{ACKNOWLEDGMENTS}

We thank the following members of the Canadian Food Inspection Agency, Charlottetown Laboratory, for their contributions to this project: Pamela Ross and Cathy Shaw for performing the diagnostic TaqMan PCR analyses, Christine Belanger, Michelle Dunbar, Bob Jenkins, Marcellin Garneau, and Brenda Peters for the serological analyses, and Christina Fields and Mark Ings for providing additional technical support. 


\section{ELISA Screening}
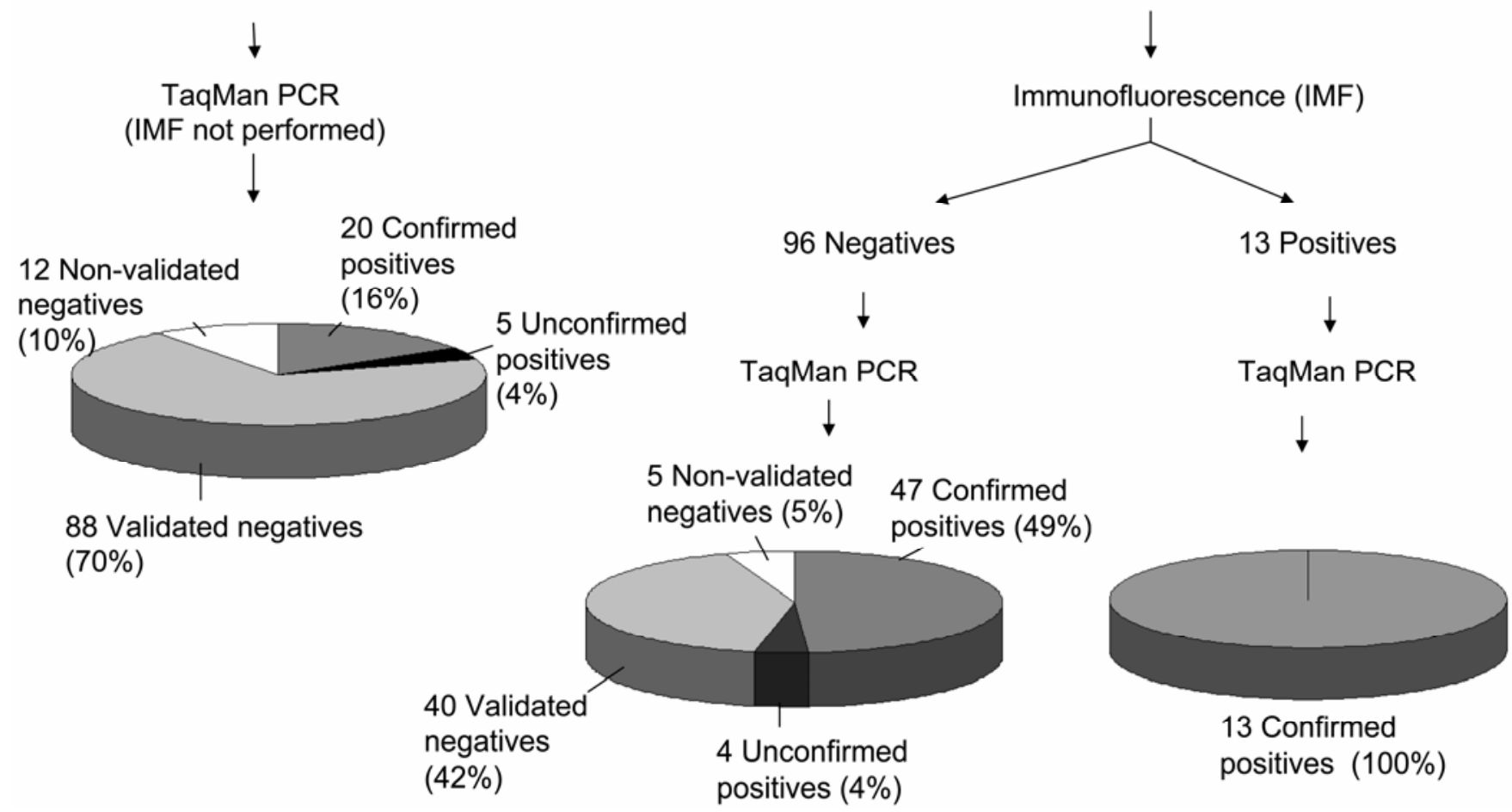

Fig. 9. Comparison of real-time polymerase chain reaction (PCR) (TaqMan assay) and serological results generated for 234 diagnostic samples tested for Clavibacter michiganensis subsp. sepedonicus. Confirmed positives were those that generated a signal in the Cy5 channel and a melt peak between 85.11 and $85.89^{\circ} \mathrm{C}$. Unconfirmed positives were those generating a signal in the Cy5 channel, but failing to generate a melt peak between 85.11 and $85.89^{\circ} \mathrm{C}$. Validated negatives were those generating no signal in the Cy5 channel, with a cycle threshold (Ct) in the FAM Channel less than 32.84 and a melt peak between 94.20 and $94.86^{\circ} \mathrm{C}$. Nonvalidated negatives either failed to generate an FAM Channel Ct less than 32.84 or failed to generate a melt peak between 94.20 and $94.86^{\circ} \mathrm{C}$.

\section{LITERATURE CITED}

1. Bach, H.-J., Jessen, I., Schloter, M., and Munch, J. C. 2003. A TaqMan-PCR protocol for quantification and differentiation of the phytopathogenic Clavibacter michiganensis subspecies. J. Microbiol. Methods 52:85-91.

2. Bickley, J., and Hopkins, D. 1999. Inhibitors and enhancers of PCR. Pages 81-102 in: Analytical Molecular Biology: Quality and Validation. G. C. Saunders and H. C. Parkes, eds. Thomas Graham House, Cambridge, UK.

3. Cubero, J., van der Wolf, J., van Beckhoven, J., and López, M. M. 2002. An internal control for the diagnosis of crown gall by PCR. J. Microbiol. Methods 51:387-392.

4. De Boer, S. H., Boucher, A., and De Haan, T. L. 1996. Validation of thresholds for serological tests that detect Clavibacter michiganenesis subsp. sepedonicus in potato tuber tissue. EPPO Bull. 26:391-398.

5. De Boer, S. H., and Copeman, R. J. 1980. Bacterial ring rot testing with the indirect fluorescent antibody staining procedure. Am. Potato J. 57:457-468.

6. De Boer, S. H., Stead, D. E., Alivizatos, A. S., Janse, J. D., Van Vaerenbergh, J., De Haan, T. L., and Mawhinney, J. 1994. Evaluation of serological tests for detection of Clavibacter michignaensis subsp. sepedonicus in composite potato stem and tuber samples. Plant Dis. 78:725-729.

7. De Boer, S. H., Ward, L. J., Li, X., and Chittaranjan, S. 1995. Attenuation of PCR inhibition in the presence of plant compounds by addition of BLOTTO. Nucleic Acids Res. 23:25672568.

8. De Boer, S. H., and Wieczorek, A. 1984. Production of monoclonal antibodies to Corynebacterium sepedonicum. Phytopathology 74:1431-1434.

9. De Boer, S. H., Wieczorek, A., and Kummer, A. 1988. An ELISA test for bacterial ring rot of potato with a new monoclonal antibody. Plant Dis. 72:874-878.

10. Firrao, G., and Locci, R. 1993. Identification of Clavibacter michiganensis subsp. sepedonicus using the polymerase chain reaction. Can. J. Microbiol. 40:148-151.

11. Franc, G. D. 1999. Persistence and latency of Clavibacter michiganensis subsp. sepedonicus in field-grown seed potatoes. Plant Dis. 83:247-250.

12. Hu, X., Lai, F.-M., Reddy, A. S. N., and Ishimaru, C. A. 1995. Quantitative detection of Clavibacter michiganensis subsp. sepedonicus by competitive polymerase chain reaction. Phytopathology 85:1468-1473.

13. Hyman, L. J., Birch, P. R. J., Dellagi, A., Avrova, A. O., and Toth, I. K. 2000. Development of a quantitative PCR-based detection system for Erwinia carotovora subsp. atroseptica on potato tubers. EPPO Bull. 30:409-411.

14. Lee, I.-M., Bartoszyk, I. M., Gundersen, D. E., Mogen, G., and Davis, R. E. 1996. Nested PCR assays for ultrasensitive detection of potato ring rot bacterium, Clavibacter michiganensis subsp. sepedonicus. Appl. Environ.
Microbiol. 63:2625-2630.

15. Li, X., and De Boer, S. H. 1995. Selection of polymerase chain reaction primers from an RNA intergenic spacer region for specific detection of Clavibacter michiganensis subsp. sepedonicus. Phytopathology 85:837-842.

16. Livak, K. J., Flood, S. J., Marmaro, J., Giusti, W., and Deetz, K. 1995. Oligonucleotides with fluorescent dyes at opposite ends provide a quenched probe system useful for detecting PCR product and nucleic acid hybridization. PCR Methods Appl. 4:357-362.

17. Mills, D., Russel, B. W., and Hanus, J. W. 1997. Specific detection of Clavibacter michiganensis subsp. sepedonicus by amplification of three unique DNA sequences isolated by subtraction hybridization. Phytopathology 87:853-861.

18. Nelson, G. A. 1982. Corynebacterium sepedonicum in potato: Effect of inoculum concentration on ring rot symptoms and latent infection.Can. J. Plant Pathol. 4:129-133.

19. Pastrik, K.-H., and Rainey, F. A. 1999. Identification and differentiation of Clavibacter michiganensis subspecies by polymerase chain reaction-based techniques. J. Phytopathol. 147:687-693.

20. Pastrik, K.-H. 2000. Detection of Clavibacter michiganensis subsp. sepedonicus in potato tubers by multiplex PCR with coamplification of host DNA. Eur. J. Plant Pathol. 106:155165.

21. Paterson, R. R. M. 2006. Internal amplification controls have not been employed in fungal 
PCR hence potential false negative results. J. Appl. Microbiol. 102:1-10.

22. Ririe, K. M., Rasmussen, R. P., and Wittwer, C. T. 1997. Product differentiation by analysis of DNA melting curves during the polymerase chain reaction. Anal. Biochem. 245:154-160.

23. Rutledge, R. G., and Coté, C. 2003. Mathematics of quantitative kinetic PCR and the application of standard curves. Nucleic Acids Res. 31:e93.

24. Schaad, N. W., Berthier-Schaad, Y., Sechler, A., and Knorr, D. 1999. Detection of Clavibacter michiganensis subsp. sepedonicus in potato tubers by BIO-PCR and an automated realtime fluorescence detection system. Plant Dis. 83:1095-1100
25. Schneider, B. J., Zhao, I. L., and Orser, C. S. 1993. Detection of Clavibacter michiganensis subsp. sepedonicus by DNA amplification. FEMS Microbiol. Lett. 109:207-212.

26. Spoth, B., and Strauss, E. 1998. Screening for genetically modified organisms in food using Promega's Wizard Resin. Promega Notes 73:23-25

27. Van Beckhoven, J. R. C. M., Stead, D. E., and van der Wolf, J. M. 2002. Detection of Clavibacter michiganensis subsp. sepedonicus by AmpliDet RNA, a new technology based on real time monitoring of NASBA amplicons with a molecular beacon. J. Appl. Microbiol. 93:840-849.

28. Van der Wolf, J. M., van Beckhoven, J. R. C.
M. Bonanats, P. J. M., and Schoen, C. D. 2001. New technologies for sensitive and specific routine detection of plant pathogenic bacteria. Pages 77-79 in: Plant Pathogenic Bacteria, S. H. De Boer, ed. Kluwer, Dordrecht, The Netherlands.

29. Ward, E., Foster, S. J., Fraaije, B. A., and McCartney, H. A. 2004. Plant pathogen diagnostics: Immunological and nucleic acid-based approaches. Anal. Appl. Biol. 145:1-6.

30. Weller, S. A., Ephinstone, J. G., Smith, N. C., Boonham, M., and Stead, D. E. 2000. Detection of Ralstonia solanacearum strains with a quantitative, multiplex, real-time, fluorogenic PCR (TaqMan) assay. J. Appl. Environ. Microbiol. 66:2853-2858. 